\title{
ANALISIS PENGARUH BRAND AWARENESS, BRAND IMAGE, ACCESSIBILITY DAN EMOTIONAL CONNECTION TERHADAP BRAND CHOICE SEPEDA MOTOR HONDA DI YOGYAKARTA
}

\author{
Ach Anwaruddin \\ Fakultas Ekonomi Universitas Sarjanawiyata Tamansiswa
}

\begin{abstract}
ABSTRAK
Tujuan dari penelitian ini adalah : (1) Untuk mengetahui pengaruh brand awareness terhadap brand choice sepeda motor honda. (2) Untuk mengetahui pengaruh brand image terhadap brand choice sepeda motor honda. (3) Untuk mengetahui pengaruh accessibility terhadap brand choice sepeda motor honda. (4) Untuk mengetahui pengaruh emotional connection terhadap brand choice sepeda motor honda.

Variabel dalam penelitian ini adalah Brand Awareness, Brand Image, Accessibility, Emotional Connection dan Brand Choice. Populasi dalam penelitian ini adalah konsumen atau pemakai sepeda motor merek honda di Yogyakarta. Teknik pengambilan sampel yang digunakan adalah accidental sampling yaitu metode pemilihan sampel yang diambil dari anggota populasi yang dipilih secara kebetulan sesuai tujuan tertentu. Teknik pengumpulan data menggunakan kuesioner. Analisis yang digunakan adalah analisa regresi berganda.

Dari hasil penelitian disimpulkan bahwa : Hasil pengujian hipotesis 1 menunjukan bahwa X1 (Brand Awareness) berpengaruh secara positif terhadap Y (Brand Choice), semakin banyak orang yang menyadari tentang Brand Awareness maka semakin meningkat pula minat konsumen untuk memilih merek tersebut. Hasil pengujian hipotesis 2 menunjukan bahwa X2 (Brand Image) berpengaruh secara positif terhadap Y (Brand Choice) semakin meningkat Brand Image maka semakin meningkat pula minat konsumen untuk memilih merek tersebut. Hasil pengujian dari hipotesis 3 menunjukan bahwa X3 (Accessibility) tidak berpengaruh secara positif terhadap Y (Brand Choice) artinya meskipun banyak orang yang memperhatikan faktor Accessibility belum tentu mempengaruhi minat para konsumen untuk memilih merek tersebut. Hasil pengujian hipotesis 4 menunjukan bahwa X4 (Emotional Connection) berpengaruh secara positif terhadap Y (Brand Choice) semakin banyak orang yang memperhatikan faktor Emotional Connection maka semakin tinggi pula minat konsumen untuk memilih merek tersebut.

Kata kunci : Brand Awareness, Brand Image, Accessibility, Emotional Connection dan Brand Choice.
\end{abstract}

\section{PENDAHULUAN}

\subsection{Latar Belakang}

Dewasa ini persaingan dalam dunia bisnis semakin ketat, termasuk usaha bisnis dalam bidang transportasi seperti motor. Masing-masing perusahaan berlomba-lomba untuk menciptakan keunggulan yang terbaik atas produk-produknya yang di tawarkan kepada konsumen, hal ini di maksudkan agar perusahaan tersebut dapat merebut pangsa pasar secara luas. Dimata konsumen produksi sepeda motor yang mempunyai kualitas dari segi model, performa mesin, ketersediaan suku cadang dan harga yang di tawarkan menjadi faktor-faktor pendukung dalam menentukan pilihan mereka.

Konsumen dalam membeli produk biasanya hanya mengingat merek yang sudah tertanam di benaknya. Hal inilah yang dapat membuat suatu pemetaan persepsi dari masing-masing konsumen, di mana antar satu merek dengan merek yang lain mempunyai keunggulan masing-masing yang akan menyebabkan suatu persaingan dalam dunia bisnis.

Akses merupakan faktor yang juga 
harus di perhatikan oleh para produsen pabrikan sepeda motor di indonesia, kemudahan dalam mencari suatu tempat atau showroom, kemudahan dalam mencari suku cadang dan kemudahan untuk memperoleh pelayanan sangat di butuhkan para konsumen. Atribut dan kelengkapan dari produk itu sendiri juga menjadi salah satu faktor mengapa para konsumen akan memilih suatu merek, semakin banyak fitur yang di tawarkan oleh suatu merek maka akan semakin tertarik pula konsumen dalam memilih merek tersebut.

Gambar atau citra suatu merek yang berkualitas dan banyak di terima oleh masyarakat serta sudah melekat di benak halayak umum ikut mempengaruhi pilihan para konsumen. Dan di tambah lagi dengan adanya ikatan emosional seperti keterikatan suatu konsumen tersebut melalui sebuah jalinan khusus semisal adanya hubungan pertemanan dengan para penjual sehingga memudahkan para pembeli untuk membeli produk tersebut. Serta pengaruh eksternal seperti pengaruh keluarga dalam memilih suatu merek atau pun ketertarikan konsumen terhadap suatu produk karena di dasarkan atas nilai sosial ataupun yang lainnya. Semua faktor tersebut dapat berpengaruh terhadap niat para konsumen untuk memilih suatu merek.

1.2 Rumusan Masalah

1.2.1 Apakah brand awareness berpengaruh terhadap brand choice sepeda motor Honda di Yogyakarta?

1.2.2 Apakah brand image berpengaruh terhadap brand choice sepeda motor Honda di Yogyakarta?

1.2.3 Apakah accessibility berpengaruh terhadap brand choice sepeda motor Honda di Yogyakarta?

1.2.4 Apakah emotional connection berpengaruh terhadap brand choice sepeda motor Honda di Yogyakarta?

\subsection{Tujuan Masalah}

Berdasarkan perumusan masalah diatas, maka tujuan dari penelitian ini adalah untuk mengetahui :

1.3.1 Untuk mengetahui pengaruh brand awareness terhadap brand choice sepeda motor Honda di Yogyakarta.

1.3.2 Untuk mengetahui pengaruh brand image terhadap brand choice sepeda motor Honda di Yogyakarta.

1.3.3 Untuk mengetahui pengaruh accessibility terhadap brand choice sepeda motor Honda di Yogyakarta.

1.3.4 Untuk mengetahui pengaruh emotional connection terhadap brand choice sepeda motor Honda di Yogyakarta.

\section{LANDASAN TEORI}

\subsection{Tinjauan Pustaka}

\subsubsection{Merek (Brand)}

Merek saat ini telah menjadi aset perusahaan yang paling bernilai. Selain sangat membantu dalam penetrasi pasar, merek yang kuat juga menciptakan loyalitas. Perusahaan atau produk yang memiliki merek yang kuat cenderung lebih mudah memenuhi kebutuhan dan keinginan sesuai dengan persepsi konsumen ( Susanto, 2008 : 14 )

Aaker ( 2004 : 9 ) merek adalah nama atau simbol yang bersifat membedakan ( seperti logo, cap atau kemasan ), yang membedakannya dari barang atau jasa yang dihasilkan oleh kompetitor, serta melindungi konsumen maupun produsen dari para kompetitor yang berusaha memberikan produk-produk yang tanpa identik.

Merek adalah identifikasi 
yang berupa nama atau simbol yang mempengaruhi proses pemilihan suatu produk atau jasa yang membedakannya dari produk pesaing serta mempunyai nilai bagi pembeli dan penjualnya.

\subsubsection{Brand Awareness}

Aaker dalam Handayani, dkk ( 2010 : 62 ), mendefinisikan kesadaran merek adalah kemampuan dari konsumen potensial untuk mengenali atau mengingat bahwa suatu merek termasuk ke dalam kategori produk tertentu. Sedangkan menurut Durianto, dkk ( 2004 : 30 ), brand awareness adalah kesanggupan seorang calon pembeli untuk mengenali, mengingat kembali suatu merek sebagai bagian dari suatu kategori produk tertentu.

Kemampuan konsumen untuk mengenali atau mengingat merek suatu produk berbeda tergantung tingkat komunikasi merek atau persepsi konsumen terhadap merek produk yang ditawarkan.

Kesadaran merek merupakan elemen ekuitas yang sangat penting bagi perusahaan karena kesadaran merek dapat berpengaruh secara langsung terhadap ekuitas merek. Apabila kesadaran konsumen terhadap merek rendah, maka dapat dipastikan bahwa ekuitas mereknya juga akan rendah.

\subsubsection{Brand Image}

Pengertian brand image menurut Fandy Tjiptono ( 2005 : 49 ) adalah deskripsi tentang asosiasi dan keyakinan konsumen terhadap merek tertentu. Brand image itu sendiri memiliki arti kepada suatu pencitraan sebuah produk dibenak konsumen secara massal. Setiap orang akan memiliki pencitraan yang sama terhadap sebuah merek. Menurut Kotler ( 2005 ) brand image yang efektif dapat mencerminkan tiga hal, yaitu :

1. Membangun karakter produk dan memberikan value proposition.

2. Menyampaikan karakter produk secara unik sehingga berbeda dengan para pesaingnya.

3. Member kekuatan emosional dari kekuatan rasional.

Susanto dan Wijanarko ( 2004 : 127 ), brand image adalah seperangkat aset dan reliabilitas merek yang berkaitan dengan suatu merek, nama dan simbolnya, yang menambah atau mengurangi nilai yang diberikan oleh suatu barang atau jasa kepada perusahaan atau pelanggan.

\subsubsection{Accessibility}

Kemudian Bambang Susantono ( 2004 : 24 ) menambahkan bahwa Aksesibilitas adalah suatu ukuran potensial atau kemudahan orang untuk mencapai tujuan dalam suatu perjalanan.

Menurut Lin dan Chang ( 2003 ), kenyamanan merek memiliki dampak yang signifikan terhadap pilihan merek konsumen. Dengan kata lain, akses mudah ke merek di toko sangat penting ketika membeli produk apapun. Aksesibilitas adalah suatu ukuran kenyamanan atau kemudahan lokasi tata guna lahan berinteraksi satu sama lain, dan mudah atau sulitnya lokasi tersebut dicapai melalui transportasi.

Dalam Kamus Bahasa Inggris Wojowasito ( $1991: 2$ ) 
mengatakan bahwa accessibility adalah hal yang mudah dicapai. Artinya aksesibilitas tidak hanya sekedar kesediaan segala sesuatu, namun juga kesediaan yang mudah dicapai.

\subsubsection{Emotional Connection}

Ikatan emosional konsumen terhadap merek yaitu berasal dari perasaan dan sikap positif dari pribadi seorang yang di tujukan terhadap produk atau merek tertentu secara keseluruhan ( Sweeney dan Soutar, 2001 ). Ikatan emosional konsumen terhdap merek memiliki pengaruh positif terhadap loyalitas konsumen. Jika konsumen telah memiliki perasaan pribadi yang positif, yaitu menyukai produk atau merek tertentu, dan percaya bahwa produk tersebut telah sesuai dengan keinginannya, serta memiliki perasaan bangga pada suatu produk atau merek yang di gunakannya, maka konsumen tersebut akan loyal terhadap produk atau merek tersebut. Penelitian Eka dan Dedi ( 2002 ) juga menyebutkan bahwa ketertarikan emosional seseorang konsumen terhadap suatu merek tertentu akan mempengaruhi tingkat loyalitasnya terhadap suatu merek tertentu akan mempengaruhi tingkat loyalitas terhadap suatu merek tersebut.

\subsection{Hipotesis}
2.2.1 $\mathrm{H}_{1}=$
Brand
Awareness
berpengaruh secara positif terhadap Brand Choice.
2.2.2 $\mathrm{H}_{2}=$ Brand Image berpengaruh secara positif terhadap Brand Choice.
2.2.3 $\mathrm{H}_{3}=$ Accessibility tidak berpengaruh secara positif terhadap Brand Choice.

\subsection{4 $\mathrm{H}_{4}=$ Emotional Connection}

berpengaruh secara positif terhadap Brand Choice.

\section{METODOLOGI PENELITIAN}

\subsection{Sifat}

Penelitian ini adalah penelitian yang bersifat kuantitatif. Metode kuantitatif adalah pendekatan ilmiah terhadap pengambilan keputusan manajerial dan ekonomi. Penelitian kuantitatif adalah penelitian ilmiah yang sistematis terhadap bagian-bagian dan fenomena serta hubungan-hubungannya. Tujuan penelitian kuantitatif adalah mengembangkan dan menggunakan model-model matematis, teori-teori dan hipotesis yang berkaitan dengan fenomena alam. Penelitian ini bermaksud menggambarkan sesuatu keadaan obyek tertentu yang memiliki hubungan atau dipengaruhi oleh faktor lain dan penarikan kesimpulannya didasarkan pada angka yang diolah secara statistik. Penelitian ini dilakukan terhadap konsumen atau pengguna produk sepeda motor merek Honda di Yogyakarta.

3.2 Metode pengumpulan data

Metode yang di gunakan dalam penelitian ini adalah Kuesioner ( angket ). Metode ini merupakan teknik pengumpulan data yang dilakukan dengan cara memberikan seperangkat pertanyaan atau pernyataan tertulis kepada responden untuk dijawabnya, dimana peneliti tidak langsung bertanya jawab dengan responden (Sugiono, $2013: 142$ ).

\subsection{Sampel}

Dalam penelitian ini menggunakan teknik Probability Sampling atau random sampling merupakan teknik sampling yang dilakukan dengan memberikan peluang atau kesempatan kepada seluruh anggota populasi untuk menjadi sampel. Pengambilan sampel dilakukan dengan menggunakan salah satu teknik yaitu accidental sampling adalah metode pemilihan sampel yang diambil dari anggota populasi yang 
dipilih secara kebetulan sesuai tujuan tertentu, yakni responden yang berjumlah 100 orang yang kebetulan membeli atau memiliki produk sepeda motor merek honda di Yogyakarta.

\subsection{Definisi Operasional}

\subsubsection{Brand Awareness}

Merek adalah identifikasi yang berupa nama atau simbol yang mempengaruhi proses pemilihan suatu produk atau jasa yang membedakannya dari produk pesaing serta mempunyai nilai bagi pembeli dan penjualnya. Merek merupakan nama, istilah, tanda, simbol, rancangan atau kombinasi dari hal-hal tersebut yang dapat di ketahui dengan kuisioner, dan di ukur jawabannya dengan skala ordinal.

\subsubsection{Brand Image}

Kesadaran merek adalah kemampuan dari konsumen potensial untuk mengenali atau mengingat bahwa suatu merek termasuk ke dalam kategori produk tertentu. Brand awareness merupakan kesanggupan seorang calon pembeli untuk mengenali, mengingat kembali suatu merek sebagai bagian dari suatu kategori produk tertentu.

\subsubsection{Accessibility}

Brand Image adalah gebyar dari seluruh asosiasi yang terkait pada suatu merek yang sudah ada dibenak konsumen. Ukuran yang menjadi pertimbangan konsumen dalam memilih atau menilai citra merek adalah merek harus memiliki kesan positif dibidangnya, reputasi tinggi, dan keunggulan mudah dikenali.

\subsubsection{Emotional Connection}

Aksesibilitas adalah suatu ukuran potensial atau kemudahan orang untuk mencapai tujuan dalam suatu perjalanan. Kenyamanan merek memiliki dampak yang signifikan terhadap pilihan merek konsumen. Dengan kata lain, akses mudah ke merek di toko sangat penting ketika membeli produk apapun.

\subsection{Analisis data}

\subsubsection{Uji Validitas}

Merupakan

proses pengukuran untuk menguji kecermatan butir-butir dalam daftar pertanyaan untuk melakukan fungsi ukurannya dimana pengujian dilakukan dengan mengkorelasikan skor pada masing-masing item dan skor totalnya. Dengan rumus Pearson Product Moment ( Riduwan, 2004 ).

\subsubsection{Uji Relibilitas}

Reliabilitas merupakan proses pengukuran pada derajat ketepatan, ketelitian, dan akurasi yang ditunjukkan oleh instrument penelitian. Penelitian ini menggunakan metode Alpha untuk melakukan estimasi reliabilitas. Teknik untuk mengetahui reliabilitas seluruh tes dengan menggunakan rumus sebagai berikut ( Riduwan, 2004 ).

\subsubsection{Metode Regresi Linier} Berganda

Alat yang digunakan adalah uji regresi Linier berganda, yaitu analisis tentang variable tergantung (Y) Dependent variable adalah brand choice, dengan variable bebas (X) Independent variable adalah brand awareness, brand image, accessibility dan emotional connection.

$$
\text { Regresi berganda }
$$


digunakan untuk mengetahui pengaruh variabel bebas terhadap variabel terikatnya secara bersama-sama. Dalam penelitian ini persamaan regresi berganda adalah ( Soehardi Sigit, 2003 : 169 ).

\subsubsection{Uji Hipotesis}

\subsubsection{Uji F}

Menurut Sugiyono ( 2005 : 266 ) uji F digunakan untuk mengetahui pengaruh secara bersama-sama variabel independen terhadap variabel dependen. Untuk mengetahui tingkat signifikansi dari pengaruh variable independent secara keseluruhan terhadap variable dependen.

1) Jika F hitung $>F$ table atau nilai signifikan ( sig ) kurang dari 5\% maka $\mathrm{H}_{0} \quad$ ditolak yang berarti signifikan atau variable independen secara keseluruhan berpengaruh terhadap variable dependen.

2) Jika F hitung $<$ F table atau signifikan ( sig ) lebih dari 5\% maka $\mathrm{H}_{0}$ diterima yang berarti tidak signifikan atau variable independen secara keseluruhan tidak berpengaruh terhadap variable dependen.

\subsubsection{Uji t}

Yaitu mengetahui tingkat signifikansi dari pengaruh variable independen secara individu terhadap variable dependen dengan menentukan hipotesis nol dan hipotesis alternative.

1) Jika t hitung $>t$ tabel atau nilai signifikansinya ( sig ) lebih dari 5\% maka $\mathrm{H}_{0}$ diterima berarti signifikan atau variable independen yang diuji secara nyata berpengaruh terhadap variable dependen.

2) Jika t hitung $<$ t tabel atau nilai signifikannya ( $\mathrm{sig}$ ) lebih dari 5\% maka $\mathrm{H}_{0} \quad$ diterima yang berarti tedak sigmifikan atau variable independent yang diuji secara nyata tidak berpengaruh terhadap variable dependen.

\section{HASIL DAN PEMBAHASAN}

4.1 Uji Validitas

Uji dilakukan bertujuan untuk menguji tingkat ketepatan dalam mengukur variable brand awareness, brand image, accessibility dan emotional connection terhadap brand choice. Untuk mengetahui apakah butir tersebut valid bisa dilakukan dengan membandingkan nilai probabilitas signifikansi dengan nilai alpha yang ditetapkan dengan ketentuan jika korelasi item dengan total item berkorelasi positif dan mempunyai nilai signifikansi kurang dan nilai alpha yang ditetapkan dalam hal ini 0,05 (5\%) maka butir tersebut dinyatakan valid.

Berdasarkan table di atas dapat diketahui bahwa 5 butir item pada variable brand awareness, brand image, 
accessibility dan emotional connection semuanya valid. Hal ini dapat kita lihat pada kolom korelasi item dan total item berkorelasi positif dengan signifikansi 0,000 dan ada tanda bintang $\left(^{*}\right)$.

4.2 Uji Reliabilitas

Hasil uji reliabilitas X1 ( Brand Awareness ) menunjukan nilai cronbach's alpha sebesar 0,723. Nilai 0,723 adalah nilai yang baik karena keandalan lebih dari 0,70 adalah baik. Hasil uji reliabilitas X2 (Brand Image) menunjukan nilai cronbach's alpha sebesar 0,697. Nilai 0,697 adalah nilai yang baik karena keandalan kisaran 0,70 bisa diterima. Hasil uji reliabilitas X3 ( Accessibility) menunjukan nilai cronbach's alpha sebesar 0,770. Nilai 0,770 adalah nilai yang baik karena keandalan lebih dari 0,70 adalah baik. Hasil uji reliabilitas X4 (Emotional Connection ) menunjukan nilai cronbach's alpha sebesar 0,664. Nilai 0,664 adalah nilai yang baik karena keandalan kisaran 0,70 bisa diterima. Hasil uji reliabilitas Y ( Brand Choice ) menunjukan nilai cronbach's alpha sebesar 0,735 . Nilai 0,735 adalah nilai yang baik karena keandalan lebih dari 0,70 adalah baik.

4.3 Regresi linier berganda

Dengan koefisien sebesar 0,207 dengan tingkat signifikansi $0,043<0,05$ yang artinya variable Brand Awareness berpengaruh terhadap pemilihan merek. Dengan koefisien sebesar 0,267 dengan tingkat signifikansi $0,009<0,05$ nilai ini yang paling tertinggi di antara variable lain yang artinya variable Brand Image sangat berpengaruh terhadap pemilihan merek. Dengan koefisien sebesar 0,029 dengan tingkat signifikansi $0,763>0,05$ yang artinya variable Accessibility tidak berpengaruh terhadap pemilihan merek. Dengan koefisien sebesar 0,243 dengan tingkat signifikansi $0,015<0,05$ yang artinya variable Emotional Connection berpengaruh terhadap pemilihan merek.

4.4 Uji Hipotesis

$$
\text { 4.4.1 Uji F }
$$

Nilai f sebesar 10,687 dengan sifnifikansi 0.000 . nilai signifikansi tersebut $<0,05$ sehingga dapat dikatakan bahwa secara serentak variable bebas berpengaruh terhadap variable terikat.

4.4.2 Uji t

- Nilai signifikansi variable X1 sebesar 0,043 yang berarti bahwa model signifikan karena signifikansi $<0,05$.

- Nilai signifikansi variable X2 sebesar 0,009 yang berarti bahwa model signifikan karena signifikansi $<0,05$.

- Nilai signifikansi variable X3 sebesar 0,763 yang berarti bahwa model tidak signifikan karena signifikansi $>0,05$.

- Nilai signifikansi variable X4 sebesar 0,015 yang berarti bahwa model signifikan karena signifikansi $<0,05$.

\subsection{Pembahasan}

Hasil dari regresi berganda dalam penelitian ini menunjukan bahwa variable bebas yang digunakan dalam penelitian ini hanya mempengaruhi variable terikat sebesar 0,281 . Hal ini menunjukan bahwa 71,9 \% factor lain yang dapat mempengaruhi pemilihan merek sepeda motor Honda di Yogyakarta.

Dari hasil regresi berganda dalam bentuk persamaan yaitu $\mathrm{Y}=0,207 \mathrm{X} 1+$ $0,267 \mathrm{X} 2+0,029 \mathrm{X} 3+0,243 \mathrm{X} 4$ dapat dilihat diantara 4 variable Brand Awareness, Brand Image, Accessibility dan Emotional Connection yang paling dominan atau yang paling berpengaruh terhadap Brand Choice adalah variable X2 ( Brand Image) dengan nilai sebesar 0,267 artinya semakin banyak orang yang memperhatikan Brand Image suatu merek sepeda motor 
seperti : Kehandalan Mesin, Inovatif dan keiritan bahan bakar, maka semakin tinggi pula minat para konsumen dalam memilih merek sepeda motor tersebut.

Hasil pengujian hipotesis 1 menunjukan bahwa X1 ( Brand Awareness ) mempengaruhi Y ( Brand Choice ) dengan koefisien sebesar 0,207 dengan tingkat signifikansi $0,043<0,05$ yang artinya variable Brand Awareness cukup berpengaruh terhadap Brand Choice.

Hasil pengujian hipotesis 2 menunjukan bahwa X2 (Brand Image) mempengaruhi Y (Brand Choice) dengan koefisien sebesar 0,267 dengan tingkat signifikansi $0,009<0,05$ nilai ini yang paling tertinggi di antara variable lain yang artinya variable Brand Image sangat berpengaruh terhadap Brand Choice.

Hasil pengujian dari hipotesis 3 menunjukan bahwa variable $\mathrm{X} 3$ ( Accessibility ) mempengaruhi $\mathrm{Y}$ ( Brand Choice) dengan koefisien sebesar 0,029 dengan tingkat signifikansi $0,763>0,05$ yang artinya variable Accessibility tidak berpengaruh terhadap Brand Choice. Oleh karena itu dalam penelitian ini dapat dilihat bahwa dalam menentukan pemilihan suatu merek sepeda motor tidak selalu berdasarkan faktor Accessibility semata. Sebuah studi serupa dilakukan baru-baru oleh Kim ( 2008 ) yang melaporkan 21 persen konsumen berperilaku dengan cara seperti, selama beberapa pembeli kendaraan, faktor aksesibilitas tidak hanya terbatas pada kendaraan semata tetapi juga ketersediaan showroom dan suku cadang. Accessibility bisa berupa ketersedian suku cadang motor, kemudian kemudahan mencari dealer motor. Akan tetapi hal tersebut masih kurang bisa di terima oleh para konsumen. Terbukti dengan hasil dari faktor ini yang masih tidak berpengaruh signifikan terhadap pemilihan suatu merek sepeda motor.
Hasil pengujian hipotesis 4 menunjukan bahwa X4 ( Emotional Connection ) mempengaruhi Y ( Brand Choice ) dengan koefisien sebesar 0,243 dengan tingkat signifikansi $0,015<0,05$ yang artinya variable Emotional Connection cukup berpengaruh terhadap Brand Choice.

\section{KESIMPULAN}

Dari hasil analisis dan pembahasan dapat disimpulkan bahwa,

5.1 Hasil pengujian hipotesis 1 menunjukan bahwa X1 ( Brand Awareness ) mempengaruhi Y ( Brand Choice ) dengan koefisien sebesar 0,207 dengan tingkat signifikansi $0,043<0,05$ yang artinya variable Brand Awareness cukup berpengaruh terhadap Brand Choice.

5.2 Hasil pengujian hipotesis 2 menunjukan bahwa X2 (Brand Image) mempengaruhi Y (Brand Choice) dengan koefisien sebesar 0,267 dengan tingkat signifikansi $0,009<0,05$ nilai ini yang paling tertinggi di antara variable lain yang artinya variable Brand Image sangat berpengaruh terhadap Brand Choice.

5.3 Hasil pengujian dari hipotesis 3 menunjukan bahwa variable X3 ( Accessibility ) mempengaruhi $\mathrm{Y}$ ( Brand Choice) dengan koefisien sebesar 0,029 dengan tingkat signifikansi $0,763>0,05$ yang artinya variable Accessibility tidak berpengaruh terhadap Brand Choice.

5.4 Hasil pengujian hipotesis 4 menunjukan bahwa X4 ( Emotional Connection ) mempengaruhi Y ( Brand Choice ) dengan koefisien sebesar 0,243 dengan tingkat signifikansi $0,015<0,05$ yang artinya variable Emotional Connection cukup berpengaruh terhadap Brand Choice.

\section{REFERENSI}

Aaker, David. A. 2004. Building Strong

Brands. New York: The Free Press.

Aaker, David. A dan Jacobson, 2004. 
Building of Brands. New York: The Free Press.

Alma, Buchari, 1998. Manajemen

Pemasaran dan Pemasaran Jasa.

Penerbit CV. Alfabeta, Bandung.

Basu Swastha, 2002, Manajemen

Pemasaran Modern, Penerbit Liberty

Yogyakarta, Yogyakarta.

Bedman Narteh, Raphael Odoom, Mahama

Braimah, Samuel Buame, Journal of

Product and Brand Management, Key

drivers of automobile brand choice in

sub-Saharan Africa : the case of Ghana,

2012.

Bernard, T. Widjaja, 2006. 10 Fenomena

Brand. Jurnal Bisnis.

http://www.labora.ac.id/?buka=jurbisut ama\&id

East, R., 1997. Consumer Behavior.

Published of Prentice Hall, London.

Hasibuan, Malayu S.P., Drs., 2002,

Manajemen Sumber Daya Manusia, edisi revisi, PT. Bumi Aksara, Jakarta.

Keller, K.L., 1993. Conceptualizing,

Measuring and Managing Customer

Based Brand equity. Published of

Prentice Hall, New Jersey.

Keller, 1999. Managing Brands For The

Long Run: Brand Reinforcement and

Revitalizaiton Strategies. Spring Vol.

41 No. 3, California Management

Review.

Kotler, Philip, 2005, Manajemen

Pemasaran, jilid a, edisi 9, lembaga penerbit FEUI, Jakarta.

Kotler, Philip, 2005, Manajemen

Pemasaran, jilid a, edisi 11, penerbit PT.

INDEKS kelompok gramedia,

Jakarta.

Kotler, Philip dan Amstrong, 2004, Dasar dasar Pemasaran, Edisi ke - 9, jilid 1, Terjemahan Aleexander Sindoro, Penerbit PT. Indeks, jakarta.

Kotler, P., \& Armstrong, G., 2004. Principles of Marketing. 10th ed. Published of Prentice Hall, New Jersey.

Kotler, Philip, 1997. Manajemen Pemasaran, Analisis Perencanaan, Implementasi dan Kontrol. Edisi 9 PT. Prenhallindo, Jakarta.

Mudrajad Kuncoro, ( 2004 ), Metode Kuantitatif : Teori dan aplikasi untuk bisnis dan ekonomi, Cetakan kedua, Penerbit Unit Penerbit dan Percetakan AMP YKPN, Yogyakarta.

Sugiono, (2013), Metode Penelitian Kuantitatif, kualitatif, dan R\&D, Penerbit Alfabeta, Bandung.

Sulistiyani, Ambar T dan Rosidah, 2003, Manajemen Sumber daya Manusia, Cetakan pertama, Graha Ilmu, Yogyakarta.

Sumarwan, Ujang, 2004, Perilaku Konsumen Teori dan Penerapannya dalam Pemasaran, PT. Ghalia, Indoneesia, Bogor.

Susanto, A.B., \& Wijanarko, H., 2004. 


\section{JURNAL MANAJEMEN VOL 5 N0. 1 JUNI 2015}

Power Branding: Membangun Merek Unggul dan Organisasi Pendukungnya. Penerbit Quantum Bisnis dan Manajemen, Jakarta.

Susanto, A.B., \& Wijanarko, H., 2004. Power Branding: Membangun Merek
Unggul dan Organisasi Pendukungnya.

Penerbit Quantum Bisnis dan Manajemen, Jakarta.

Tjiptono, Fandi, 2001, Strategi Pemasaran, Edisi ke - 2, Andy Offset, Yogyakarta. 